\title{
Wildlife collections of Royal Palace Museums in The West Region of Cameroon with a Focus on wildlife conservation.
}

\author{
Mohamed Mounir Mfonden Poumie ${ }^{1}$, Peter Coals ${ }^{2,3}$, Félix Meutchieye ${ }^{4 *}$, Olivier Miantsia \\ Fokam ${ }^{1}$ \\ ${ }^{1}$ D epartment of Forestry, Faculty of Agronomy and Agricultural Sciences, University of D schang, \\ Cameroon. mfondenpoumie@gmail.com P.O. Box 222 D schang. \\ ${ }^{2}$ Wildlife Conservation Research Unit, Department of Zoology, University of Oxford, Recanati- \\ Kaplan Centre, Tubney House, Abingdon Road, Tubney, OX13 5QL, UK. peter.coals@zoo.ox.ac.uk \\ ${ }^{3}$ School of Animal, Plant \& Environmental Science, University of the Witwatersrand, Johannesburg \\ 2000, South Africa. \\ ${ }^{4}$ D epartment of Animal Science, Faculty of Agronomy and Agricultural Sciences, University of \\ D schang, Cameroon. fmeutchieye@gmail.com P.O. Box 222 D schang \\ *Corresponding author
}

\begin{abstract}
The royal palace museums of the G rassfields' Kingdoms of West Region of Cameroon are well recognized for the preservation of culturally significant objects and practices. To date, the role of palace museums in wildlife conservation has received little consideration. Herein, a preliminary study into the animalbased artefacts of palace museums from a wildlife conservation perspective is presented. A total of 11 chiefdom palace museums in the West Region of Cameroon were surveyed and the animal species represented in their exhibitions recorded. Parts of 32 different animal species, including locally extinct large mammals such as lion, cheetah, chimpanzee, and elephant were found. The primary purpose for inclusion of specimens in palace museums was for preservation of culture. However, potential wildlife conservation focused uses to which palace museums may also put their collections are discussed herein.
\end{abstract} KeyWords: Grassfields, Bamileke, Bamoun, Culture, Education, Mammals.

\section{Résumé}

Les musées du palais royal des royaumes des Grassfields de la région de l'O uest Cameroun sont bien connus pour la préservation d'objets et de pratiques culturellement significatifs. À ce jour, le rôle des musées de palais dans la conservation de la faune a été peu pris en compte. Ici, une étude préliminaire des collections animales de ces musées du point de vue de la conservation de la faune est présentée. Onze musées de palais de chefferies de la région de l'O uest Cameroun ont été étudiés et les espèces animales représentées dans leurs expositions ont été enregistrées. D es parties de 32 espèces animales différentes, y compris de grands mammifères localement disparus comme le lion, le guépard, le chimpanzé et l'éléphant ont été découverts. Le but principal de l'inclusion de spécimens dans les musées du palais est la préservation de la culture. Cependant, les utilisations potentielles axées sur la conservation de la faune auxquelles les musées de palais peuvent également mettre leurs collections sont discutées ici.

\section{Mots clés:}

Received: 18/ 12/ 2020

Accepted: 17/ 01/ 2021

D OI: https/ / dx.doi.org/ 10.4314/ jcas.v16i2.5

(C) The Authors. This work is licensed under the Creative Commons Attribution 4.0 International Licence. 


\section{Introduction}

The Grassfiedds region of western Cameroon is renowned for its traditional chiefdoms (chieftaincies), represented by Kings or Fons, and in particular their royal palaces and treasuries. The presence of treasuries in royal palaces pre-dates colonial conceptions of museums in Cameroon and speaks to a tradition of the preservation of artefacts and objects of cultural significance amongst Grassfields Kingdoms (Fubah, 2016a). Royal residences of the chieftaincies were traditional centers of political, economic, and social affairs (Ghomsi, 1985). Although colonial and post-colonial administrations have brought considerable changes in governance to Cameroonian society, local kingdoms and their associated chieftaincies continue to have contemporary cultural and political significance in western Cameroon (Rowlands, 2011; Grace, 2015). Traditional royal treasuries have been considered to be a representation of the power base of kingdoms through display of material and religious objects (Fubah, 2016a). The treasuries also serve as cultural archives and may foster a sense of belonging and oneness in kingdoms' people from generation to generation (Afigbo, 1986). The roles of treasuries and religious shrines are traditionally intertwined; as places to cater for secret societies and the gods of the land and also containing works of art and depictions of the evolution of that particular society (Talla, 2003).

There is a documented growing interest in more 'modern-style' palace museums amongst the Grassfields' Kingdoms (Fubah, 2013). Modernstyle museums are typified by movement away from private and restricted royal treasuries to openly displayed collections with wider accessibility to the public (Fubah, 2016a). Such presentations of cultural materials have been suggested to act as a democratizing force within the hierarchical structure of chieftaincies, especially pertaining to the accessibility of objects of cultural significance and sites of sacred mysteries (Fubah, 2016a). Amongst the aims of modern-style museums is the protection of cultural and artistic heritage, training and employment of young people, and the general promotion of cultural and economic development (Fubah, 2013). Modern-style museums appear to be generally accepted and have recently increased in number despite concerns over the exposure of secret and mystical objects which traditionally contribute to the status of the Fons (Fubah, 2016b).

Scholarship concerning the treasuries and museums of the $\mathrm{G}$ rassfields has taken a range of perspectives; with anthropological, sociological, artistic, and political veins of thought predominating (e.g. Rowlands, 1985; Geary, 1988). In addition, consideration has been given to the ecological value of traditional sacred sites within Grassfields palace complexes, particularly sacred forest groves which serve as ecological refugia in deforested surroundings (Fomin, 2008). Sacred natural sites are well recognized as important contributors to biodiversity conservation (e.g. Rutte, 2011; Anderson, 2016). For example, Angwafo \& Chuo (2016) state that traditional knowledge, through certain dietary prohibitions and rituals, contributes to the conservation of gorillas, chimpanzees, and buffalo in North-West Cameroon. Increased consideration of traditional uses of wildlife in Cameroon has been suggested to help solve important conservation problems related to wildlife management and traditional stewardship (Bobo \& Weladji, 2011).

Symbolism attached to animals is an important aspect of $\mathrm{G}$ rasslands cultures, where animal products and artistic representations fulfil a variety of purposes, including traditional 
medicine, decoration, and exemplification of a range of cultural and traditional values (Bobo \& Ntumwel, 2010). Animal products are thus often represented in royal treasuries and palace museums.

The highland regions of western Cameroon are noted for high levels of vertebrate endemism (e.g. WWF, 2020). However, the region is subject to extensive human encroachment which has led to the loss of much of its native large fauna (Lamarque et al., 1990; Ingram \& Nsom, 2007; Pemunta \& Anye, 2019). Indeed, none of the highland ecoregion is formally protected (WWF 2020) and large mammals such as elephant, lion, and buffalo have been extirpated (e.g. Maisels et al., 2001). Herein we consider the collections of the royal palace museums of the Grassfields Kingdoms from a wildlife conservation perspective. Little has been written about the wildlife conservation potential of the specimens contained within the collections of royal palaces in Cameroon; with the majority of existing work having focused instead on cultural preservation. As a preliminary investigation into the wildlife conservation potential of palace museum collections, in a region that is largely devoid of large wild fauna, we systematically documented wildlife species on display in royal palace museums in the Grassfields of the West Region of Cameroon and discuss the wildlife collections of royal palace museums with respect to contemporary wildlife conservation.

\section{Materials and Methods}

This study focused on chieftaincies in the Grassfields of the West Region of Cameroon. The West Region is the smallest of Cameroon's ten regions by area, yet it has one of the highest population densities in Cameroon. The region is dominated by two major ethnic groups: the Bamileke and the Bamoun (Marchal \& Perrois, 1993). The groups share cultural similarities and each organises itself in sub-groups which fall under the leadership of traditional Chiefs (Fons). These chieftaincies are hierarchically organised; the West region of Cameroon counts 11 firstdegree chieftaincies, 108 second degree and over five hundred third degree. In this study only firstdegree chieftaincies were considered: The Bamoun sultanate in the Noun Division; Babadjou, Bangang and Batcham of the Division of Bamboutos; Foto and Bafou of the Menoua Division; Banka and Bana of the Higher Nkam Division; Bamougoum of the Division of Mifi; Bangangte of the Division of Nde; and Bandjoun of the Division of Koung-khi (Figure 1).

\section{Survey tool}

Data were collected through semi-structured questionnaires presented to royal palace museum staff. Relevant questions to this work concerned the animal specimens or derivatives present in the displays. Specifically, staff were asked to list the names of species present in displays, which were then verified using field guides and online image searches. The particular body part used in the display was also recorded along with the primary reason for the animal being in the collection which included indication of its cultural symbolism. We also noted whether a number of basic pieces of information generally associated with samples in 'scientific-style' zoological museum collections and the permitting regulations for the possession of animal products in Cameroon were recorded with the sample. This information pertained to: collector's name and address, species of sample, sex of sample, age/ life-stage of sample, reproductive status of sample, location of sample origin, date of collection, and sample measurements. 


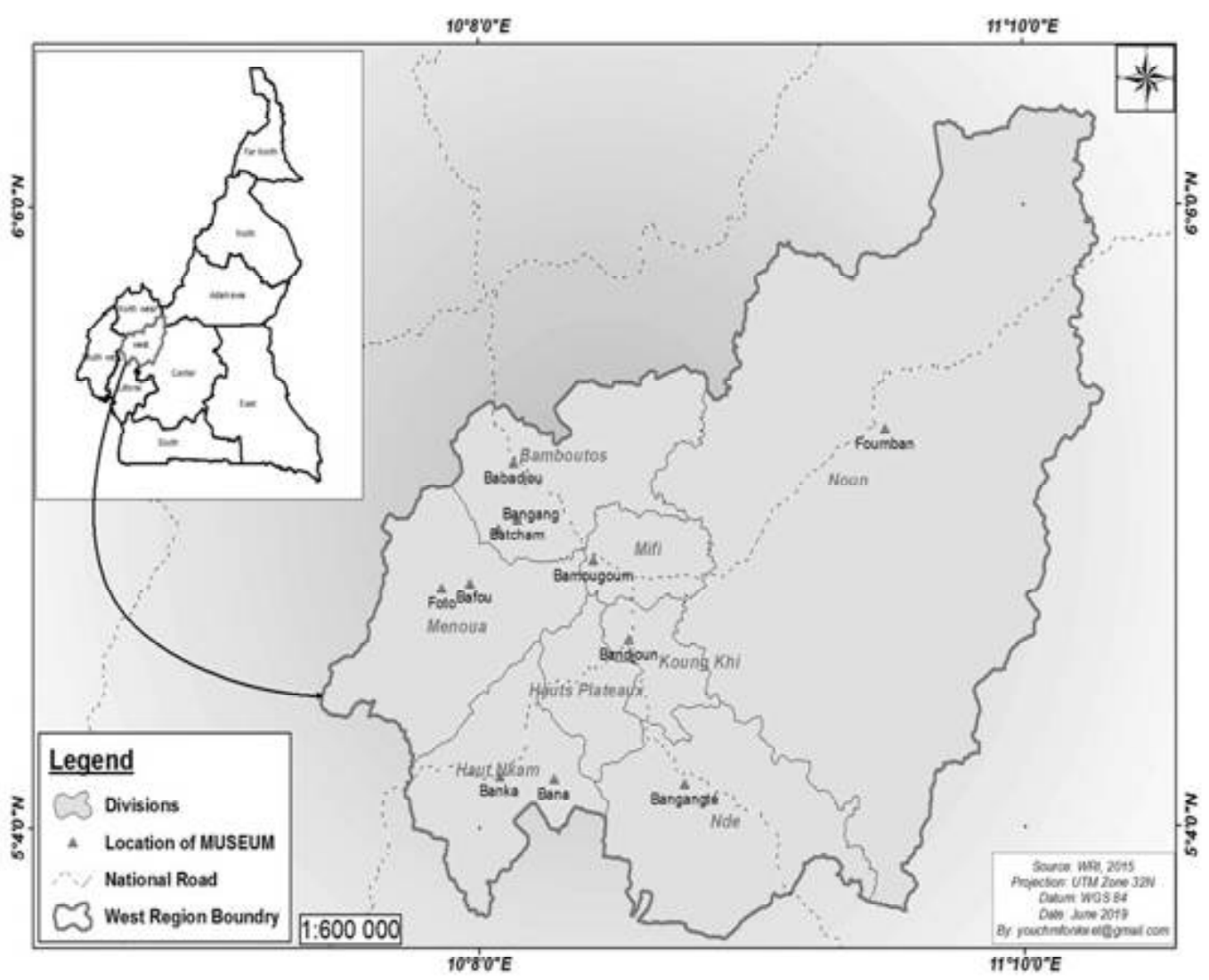

Figure 1: Location of palace museums of first-degree chieftaincies within the West Region of Cameroon.

\section{Results}

In total 32 animal species were recorded in the collections of royal palace museums. The most commonly represented species was buffalo (Synceus caffe) (19), followed by duiker species (Cephalophussp) (9), and leopard (Panthera pardus) (6). Notable other large mammal species recorded in museums that have been extirpated or are generally believed to be absent from the highland $\mathrm{G}$ rassfields region included, amongst others, lion, cheetah, chimpanzee, and elephant (Table 1).

The primary role of the presence of animal parts in royal palace museums is for cultural conservation (see Appendix 1). Animal parts are thus typically displayed as works of art and other products (Figure 2) and not as 'scientific' zoological specimens, though some are represented as preserved body parts (Figure 3) and full or partial skins (Figure 4). Indeed, skins were the most frequently encountered samples of animals $(38,45.8 \%)$, followed by horn (11, $13.3 \%)$, then crown (cranium) $(9,10.8 \%)$ (Figure 5). The mode of presentation is generally within the framework of narrating the history of the chieftaincy or the unfolding of specific cultural events or rituals for which each animal object was recorded to have a special significance.

It was noted that the majority of basic information relating to exhibit samples was unknown (Table 2). 
Table 1: Species found in palace museums in the West Region, Cameroon.

\begin{tabular}{|c|c|c|c|c|}
\hline No. & & Species & Frequency & $\begin{array}{l}\text { Present in the West } \\
\text { Region (modern day) } \\
\text { (Yes/ No) }\end{array}$ \\
\hline & Common Name & Scientific Name & & \\
\hline 1 & Brush-tailed porcupine & Athenunsaficanus & 3 & Yes \\
\hline 2 & Bushbuck & Tragdaphusstivatiaus & 1 & Yes \\
\hline 3 & African Buffalo & Synceruscaffer & 19 & Yes \\
\hline 4 & Cheetah & Adinanyx jubatux & 1 & No \\
\hline 5 & Chimpanzee & Pan panisars & 2 & No \\
\hline 6 & Cobra & Naja spp & 2 & Yes \\
\hline 7 & Cow & Bostaunus & 1 & Yes \\
\hline 8 & Cowry & Cyprace spp & 2 & No \\
\hline 9 & Crocodile & Croodytus nitctias & 1 & No \\
\hline 10 & D uiker & Cephalophusspp & 9 & Yes \\
\hline 11 & Elephant & Loxodonta aficana aficana & 3 & No \\
\hline 12 & Genet & Genetta genetta & 1 & No \\
\hline 13 & Goat & Capra spp & 1 & Yes \\
\hline 14 & Green mamba & Dendroaspisjamesconi & 1 & Yes \\
\hline 15 & Guinea fowl & Numida matagis & 1 & Yes \\
\hline 16 & Hartebeest & Aldaphus busdaphus & 2 & Yes \\
\hline 17 & Hippopotamus & Hippopdamus amphibius & 3 & Yes \\
\hline 18 & Horse & Equusspp. & 1 & Yes \\
\hline 19 & Leopard & Panthera pardus & 6 & No \\
\hline 20 & Lion & Pantherale & 3 & No \\
\hline 21 & Mussels & Mytilusspp & 2 & No \\
\hline 22 & Porcupinefish & Diodon nidhemenus & 1 & No \\
\hline 23 & Puku & Kdausvardoni & 2 & Yes \\
\hline 24 & Python & Python sabae & 1 & Yes \\
\hline 25 & Red Viper & Atheis squamigera & 2 & No \\
\hline 26 & Sable antelope & Hippotragus niger & 1 & Yes \\
\hline 27 & Sassaby & Damalisauslunatus & 2 & Yes \\
\hline 28 & Turtle & Chdonia spp & 1 & No \\
\hline 29 & Sheep & Ovisanies & 2 & Yes \\
\hline 30 & Sitatunga & Tragdaphusspdke & 4 & No \\
\hline 31 & Sparrow hawk & Acapiter spp & 1 & Yes \\
\hline 32 & African bush viper & Atheis spp & 1 & Yes \\
\hline
\end{tabular}


REVUE DE L'ACADEMIE DES SCIENCES DU CAMEROUN Vol. 16 No. 3 (mars 2021)

Appendix 1: Reasons for the presence of trophies in museums

\begin{tabular}{|c|c|c|c|c|}
\hline Species & & Part & Cultural use & $\begin{array}{l}\text { General } \\
\text { cultural } \\
\text { significance }\end{array}$ \\
\hline Common name & Scientific name & & & \\
\hline Brush-tailed porcupine & $\begin{array}{ll}\begin{array}{l}\text { Atherunus } \\
\text { aficanus }\end{array} & \mathrm{S} \\
\end{array}$ & Spine & Headgear & Protection \\
\hline Bushbuck & $\begin{array}{l}\text { Tragdaphus } \\
\text { sylvatiaus }\end{array}$ & Skin & Mat for notables & Prestige \\
\hline \multirow[t]{8}{*}{ Buffalo } & \multirow[t]{8}{*}{ Synceruscaffer } & \multirow[t]{3}{*}{ Skin } & Shield & Protection \\
\hline & & & Fabricate fetish bag & Mystical \\
\hline & & & Produce warriors' drum & Ethno-music \\
\hline & & Crown & $\begin{array}{l}\text { Seat for "Mfonpit" (the } \\
\text { minister of defence) at the first } \\
\text { ministry of the Bamoun } \\
\text { kingdom }\end{array}$ & Prestige \\
\hline & & \multirow[t]{2}{*}{$\begin{array}{l}\text { Horn } \\
\end{array}$} & Royal cup & Prestige \\
\hline & & & $\begin{array}{l}\text { Flute used for communication } \\
\text { during wars }\end{array}$ & Ethno-music \\
\hline & & \multirow[t]{2}{*}{ Tail } & Produce royal whip & Prestige \\
\hline & & & Warrior's headgear & Prestige \\
\hline Cheetah & Aanonyx jubatus & Skin & Royal mat & Prestige \\
\hline \multirow[t]{2}{*}{ Chimpanzee } & \multirow[t]{2}{*}{ Pan panisars } & Tooth & Soothsaying & Mystical \\
\hline & & Skull & Placed on soothsayer's calabash & Mystical \\
\hline Cow & Bostaunus & Horn & Communal cup & Utensil \\
\hline \multirow[t]{3}{*}{ D uiker } & \multirow[t]{3}{*}{$\begin{array}{l}\text { Cephalqphus } \\
\text { munticda }\end{array}$} & Skin & Common drums & Ethno-music \\
\hline & & & D ecorate fetish calabash & Mystical \\
\hline & & Hoof & Decorate royal pipes & Prestige \\
\hline \multirow[t]{4}{*}{ Elephant } & \multirow[t]{4}{*}{ Loxodnta aficana } & Bone & Making jewelleries & Decoration \\
\hline & & $\begin{array}{l}\text { Jaw } \\
\end{array}$ & Making jewelleries & Decoration \\
\hline & & Tooth & Making jewelleries & Decoration \\
\hline & & & Defence to the throne & Prestige \\
\hline Genet & Genetta genetta & Skin & Royal mat & Prestige \\
\hline Goat & Capra spp & Horn & $\begin{array}{l}\text { Worn to execute the warrior } \\
\text { walk during the Nguon }\end{array}$ & Protection \\
\hline \multirow[t]{2}{*}{ Hartebeest } & \multirow[t]{2}{*}{ Aldaphusbusdaphus } & \multirow[t]{2}{*}{ S Crown } & Hide secret objects & Mystical \\
\hline & & & $\begin{array}{l}\text { Execute the panjé (secret } \\
\text { society for the Bamouns) } \\
\text { traditional dance }\end{array}$ & Totem \\
\hline \multirow[t]{3}{*}{ Hippopotamus } & \multirow[t]{3}{*}{$\begin{array}{l}\text { Hippoptams } \\
\text { amphibius }\end{array}$} & Jaw & $\begin{array}{l}\text { Seat for the "Nkam" (notables) } \\
\text { at the first ministry of the } \\
\text { Bamoun kingdom }\end{array}$ & Prestige \\
\hline & & Tail & Treat poisoning & $\begin{array}{l}\text { Traditional } \\
\text { medicine }\end{array}$ \\
\hline & & Skull & $\begin{array}{l}\text { Seat for the "Nkam" (notables) } \\
\text { at the first ministry of the } \\
\text { Bamoun kingdom }\end{array}$ & Prestige \\
\hline \multirow[t]{2}{*}{ Horse } & \multirow[t]{2}{*}{ Equusspp } & \multirow[t]{2}{*}{ Tail } & $\begin{array}{l}\text { Fabricate wipe for Bamileke } \\
\text { chiefs and noblemen, a symbol } \\
\text { of the victory of life over death }\end{array}$ & Prestige \\
\hline & & & $\begin{array}{l}\text { Fabricate whip for the Bamoun } \\
\text { princess }\end{array}$ & Prestige \\
\hline \multirow[t]{3}{*}{ Lion } & \multirow[t]{3}{*}{ Pantheralø } & Skin & Royal mat & Prestige \\
\hline & & & $\begin{array}{l}\text { Totem to the person who } \\
\text { carries to execute traditional } \\
\text { dance }\end{array}$ & Prestige \\
\hline & & Skull & Trophy to great hunters & $\begin{array}{l}\text { Hunting } \\
\text { trophy }\end{array}$ \\
\hline \multirow[t]{2}{*}{ Puku } & \multirow[t]{2}{*}{ Kdas vardoni } & Crown & Hide secret objects & Mystical \\
\hline & & Crown & Trophy to hunters & $\begin{array}{l}\text { Hunting } \\
\text { trophy }\end{array}$ \\
\hline
\end{tabular}




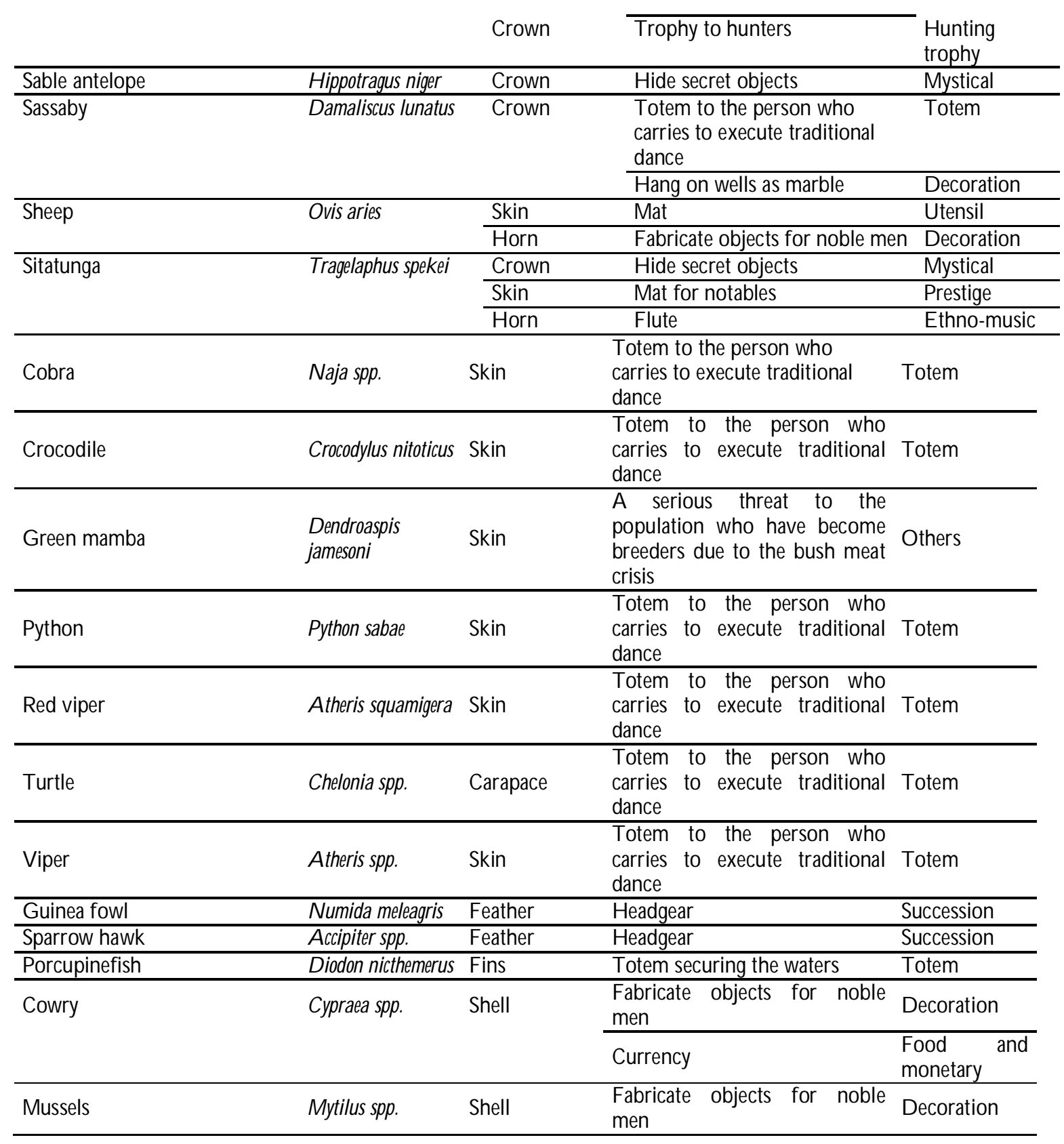


a.)

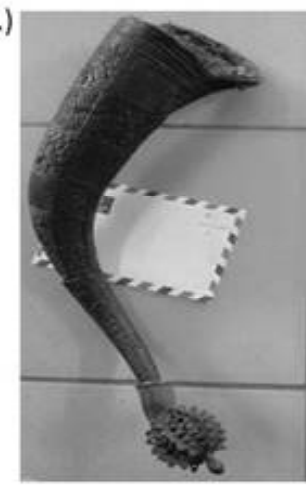

c.

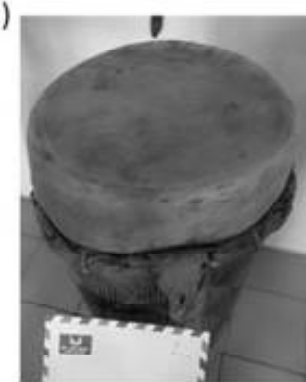

b.)

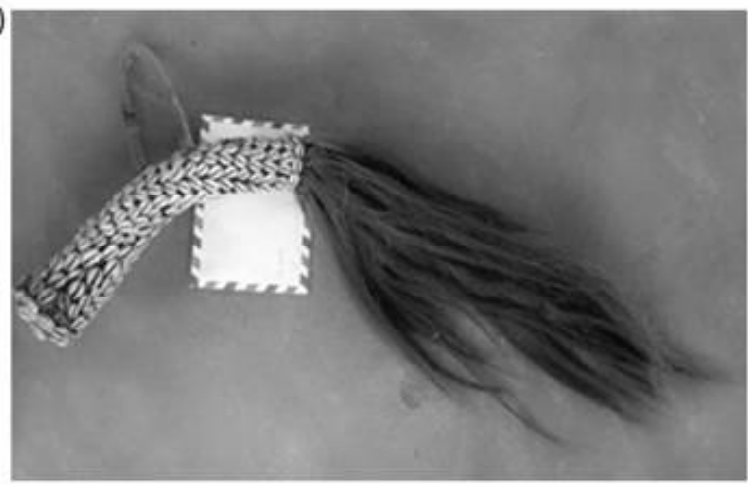

d.)

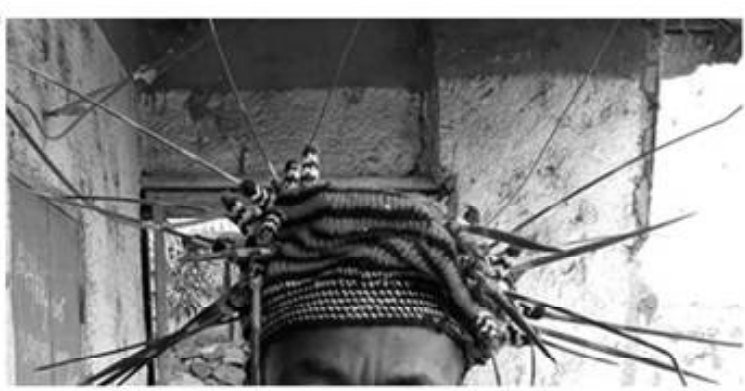

a.) Buffalo horn used as royal cup b.) Buffalo tail used as royal whip c.) D uiker skin used in drum d.) Porcupine spine used in traditional headgear

Figure 2. Examples of animal-based cultural items displayed in G rassfield palace museums

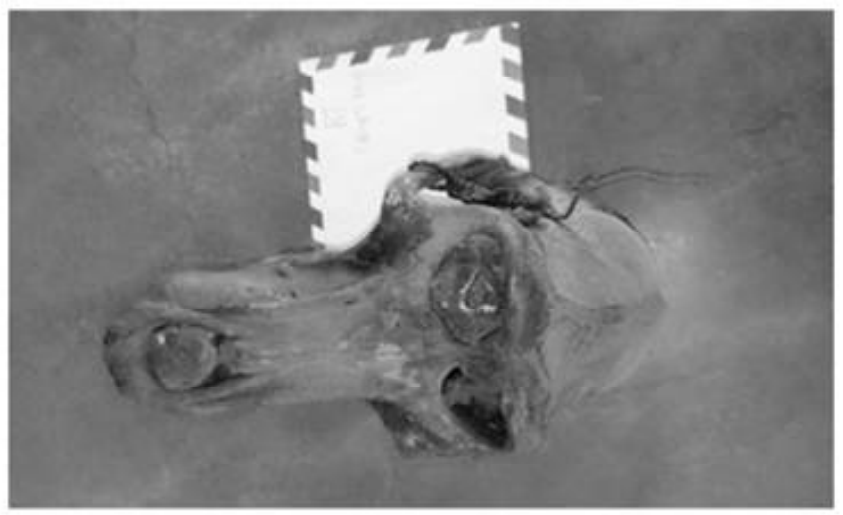

Figure 3: Chimpanzee skull used for soothsaying.

a.)

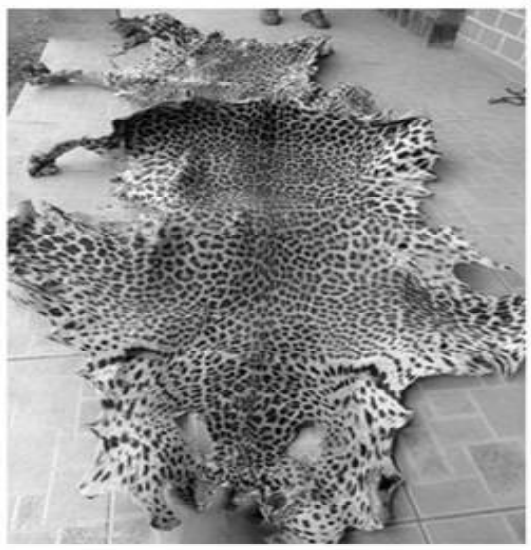

b.)

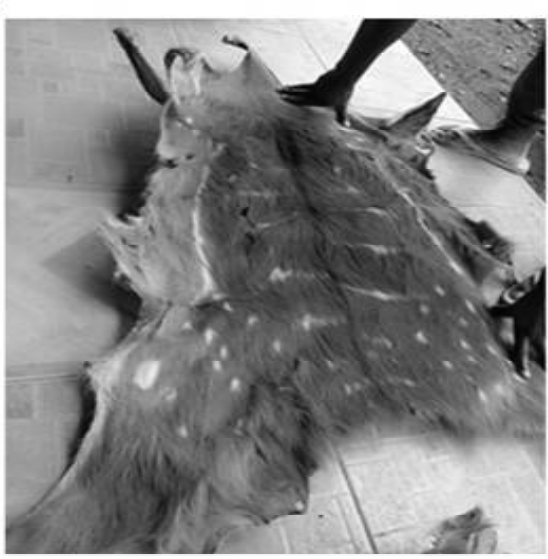

a.) Leopard skin used as royal mat b.) Sitatunga skin used as mat

Figure 4. Examples of animal skins on display in palace museums 


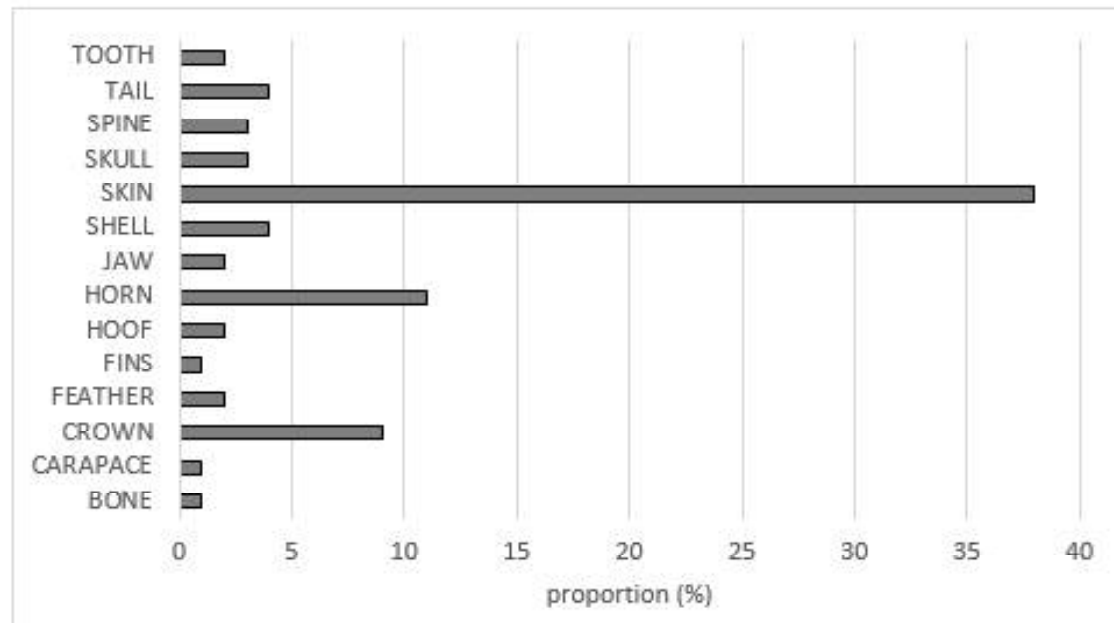

Figure 5: Animal parts found in palace museums as a proportion of total exhibits observed

Table 2: Basic museum collection information associated with animal-based exhibits

\begin{tabular}{|c|c|c|}
\hline \multicolumn{3}{|c|}{ COLLECTOR'S NAME } \\
\hline & Frequency & Percentage (\%) \\
\hline UNKNOWN & 83 & 100 \\
\hline KNOWN & 0 & 0 \\
\hline \multicolumn{3}{|c|}{ COLLECTOR'S ADD RESS } \\
\hline & Frequency & Percentage (\%) \\
\hline UNKNOWN & 83 & 100 \\
\hline KNOWN & 0 & 0 \\
\hline \multicolumn{3}{|c|}{ SPECIE S CONCERNED } \\
\hline & Frequency & Percentage (\%) \\
\hline UNKNOWN & 22 & 26,5 \\
\hline KNOWN & 61 & 73,5 \\
\hline \multicolumn{3}{|c|}{ SPECIES' SEX } \\
\hline & Frequency & Percentage (\%) \\
\hline UNKNOWN & 83 & 100 \\
\hline KNOWN & 0 & 0 \\
\hline \multicolumn{3}{|c|}{ SPECIE S' ORIG IN } \\
\hline & Frequency & Percentage (\%) \\
\hline UNKNOWN & 83 & 100 \\
\hline KNOWN & 0 & 0 \\
\hline \multicolumn{3}{|c|}{ SPECIES'AGE } \\
\hline & Frequency & Percentage (\%) \\
\hline UNKNOWN & 83 & 100 \\
\hline KNOWN & 0 & 0 \\
\hline \multicolumn{3}{|c|}{ DATE OF COLLECTION } \\
\hline & Frequency & Percentage (\%) \\
\hline UNKNOWN & 77 & 92,8 \\
\hline KNOWN & 6 & 7,2 \\
\hline \multicolumn{3}{|c|}{ SPECIE S' HABITAT } \\
\hline & Frequency & Percentage (\%) \\
\hline UNKNOWN & 76 & 91,6 \\
\hline KNOWN & 7 & 8,4 \\
\hline \multicolumn{3}{|c|}{ REPRODUCTIVE STATUS } \\
\hline & Frequency & Percentage (\%) \\
\hline UNKNOWN & 83 & 100 \\
\hline KNOWN & 0 & 0 \\
\hline
\end{tabular}




\section{D iscussion}

In this preliminary study, royal palace museums of the Grassfields, first class kingdoms in the West Region of Cameroon were surveyed and animal species represented by specimens exhibited in their collections were recorded. The primary role of specimens in these museums is for cultural purposes and are tied to traditional practices of the Bamoun and Bamileke chieftaincies. Nevertheless, samples of animals present in palace museums might also serve potential roles relating to wildlife conservation. Although the dates and locations of collection of specimens were largely unknown it is likely that many of the specimens are historical and hence may represent past populations of species that are no longer found within the Grassfields of the West Region. Specifically, buffalo, elephant, hippopotamus, lion, cheetah, and chimpanzee were represented in palace collections. These species are largely extirpated or otherwise absent from much or all of the West Region of Cameroon (e.g. Lamarque, 1990; Maisels et al., 2001; Bauer et al., 2015; D urant et al., 2015; Hulme et al., 2016; Lewison et al., 2017; IUCN SSC Antelope Specialist Group, 2019). These samples may thus represent relics of past populations of fauna of the West Region $G$ rasslands kingdoms that were historically collected locally. However, they could also be items that have been brought into the kingdoms from further afield. Future work could usefully focus on determining the extent to which the origins of these samples might be ascertained; through qualitative interviews, or genetic methods.

The applications of historical museum samples to wildlife conservation have grown with the burgeoning of Andent DNA techniques, particularly the analysis of past wildlife populations as part of the field of conservation genetics (Leonard, 2008). The extent of DNA damage and degradation is crucial in determining the eventual usefulness of the sample for genetic purposes. It is unknown whether the samples preserved in palace museums yield DNA of sufficient quality, however with constant advances in ancient D NA extractions and analyses it may prove possible to produce reliable data from samples of animals in palace museums - we highlight this as a topic for future study. West African populations of a number of the species we found represented in palace museums are small, fragmented, and threatened. Ancient DNA has proven useful in exploring the demographic history of fragmented wildlife populations and setting conservation priorities; as has been seen for West African lion (Bertola et al., 2011; Barnett et al., 2014; Henschel et al., 2014). However, pragmatically, we highlight the potentially unsuitable conditions of long-term storage and sample processing in palace museums that may have rendered samples unsuitable for robust genetic analyses. We also note the existence of extensive historical wildlife collections held by former colonial powers and national museums, the preservation conditions of which may be more conducive to such studies. Even if of no great consequence to studies of the conservation genetics of Cameroonian wildlife we suggest that the presence of samples in decentralised local collections such as palace museums might, with careful thought and development, usefully foster a sense of inclusivity in this aspect of 'modern' wildlife conservation by the traditional leadership and people of the Grassfields Kingdoms and further mobilize the longstanding museum/ collection culture of the region as an empowering post-colonial asset.

Further to the engagement of local people with wildlife conservation and management, palace museums represent a significant potential local educational resource. In accordance with the history of palace collections and the more recent 
cultural educational aims surrounding the modernisation of collections these areas are already managed as inclusive educational spaces for both the local population and visitors (e.g. Fubah, 2013). Indeed, as wilderness symbolism continues to be an important aspect of the modern material cultures of the region (e.g. Fubah, 2014), and given the importance of traditional knowledge demonstrated for wildlife conservation in western Cameroon (e.g. Angwafo \& Chuo, 2016), future work could usefully focus on exploring in depth the role of animal-based culturally-focused exhibits in contemporary environmental education.

Cameroon's regulations concerning animal trophies and collections do not explicitly address local and palace museum exhibits. Nevertheless, they do state that anybody wishing to keep wild animals, carcasses and trophies shall be required to obtain a certificate of origin issued by the services in charge of wildlife (Section 43, decree no. 95-466-pm, 20 July 1995). The unknown provenance and age of many of the animal derivatives displayed in palace museums may therefore be problematic from a regulatory perspective, particularly if contemporary specimens of protected wildlife continue to be acquired by palace museums. Indeed, we heard that recent enthusiasm for museum collections in the region may have stimulated the acquisition of new animal products by palace museums. We suggest that chemical dating techniques may be useful in better ascertaining the age of specimens - particularly concerning whether they pre-date current wildlife harvesting regulations. Pemunta \& Anye (2019) highlight the need to balance wildlife harvesting regulation with sensitivity to traditional cultural practice and note that without sensitive and reasonable alignment of regulatory mechanisms with traditional uses wildlife conservation aims might be jeopardised. Likewise, we highlight the need for further consideration of the role and purview of wildlife conservation regulations in the management of palace museums that inclusively consider a wide range of stakeholders to ensure the effective preservation of both wildlife populations and cultural traditions.

\section{Conclusion}

We found 32 animal species represented in the palace museum collections of Grassfields' Kingdoms in the West Region of Cameroon, including several species that are locally extinct in the region. Although the primary function of these collections is cultural preservation, we believe there are additional benefits that may be brought to wildlife conservation through these collections. We particularly highlight the potential for decentralised, accessible museums to contribute to local environmental education and urge further holistic consideration of the development of the educational potential of these collections in relation to wildlife conservation. We are mindful of a lack of formal regulation of the wildlife specimens of palace museums and acknowledge potential complexities in the application of regulations to these important cultural sites. We urge that careful consideration to be given to both the preservation of culture and wildlife populations in the exhibition of animal specimens in the Grassfields Kingdoms.

\section{Authors contributions: \\ MMMP \& FM conceptualized the study. \\ MMMP collected data. MMMP wrote the first draft of the manuscript. PC \& $\mathbf{O M F}$ assisted with framing the study and contributed to the writing of the final manuscript. FM supervised MMP.}

\section{Acknowledgements}

The authors are thankful to all the traditional rulers in the West Region of Cameroon. They also extend special thanks to the inhabitants of the 
West Region of Cameroon, and particularly to the museum attendants who assisted with this study.

\section{References}

Afigbo A.E. (1986). Archaeology and the Schools. In West African Journal of Archaeology Vol.16:155- 164.

Anderson, E. N. (2016). Caring for place: Ecology, ideology, and emotion in traditional landscape management. Routledge, Oxford.

Angwafo TE, Chuo MD (2016). Contributions of Indigenous Knowledge of $\mathrm{G}$ orilla (Gorilla gorilla diehi), Chimpanzee (Pantrogoottes dlici) and Buffalo (Syncenuscaffe) Conservation, in Waindow, North West Cameroon. Annual Research \& Review in Biology 11(2): 1-14, 2016, Article no.ARRB.28428 ISSN: 2347-565X, NLM ID: 101632869

Barnett, R., Yamaguchi, N., Shapiro, B., Ho, S. Y., Barnes, I., Sabin, R., \& Larson, G. (2014). Revealing the maternal demographic history of Panthera leo using ancient D NA and a spatially explicit genealogical analysis. BMC Evolutionary Biology, 14(1), 1-11.

Bauer, H., Chapron, G., Nowell, K., Henschel, P., Funston, P., Hunter, L. T., ... \& Packer, C. (2015). Lion (Panthera leo) populations are declining rapidly across Africa, except in intensively managed areas. Proceedings of the National Academy of Sciences, 112(48), 1489414899.

Bertola, L. D., Van Hooft, W. F., Vrieling, K., Uit de Weerd, D. R., York, D. S., Bauer, H., ... \& Van Haeringen, W. A. (2011). Genetic diversity, evolutionary history and implications for conservation of the lion (Panthera leo) in West and Central Africa. Journal of Biogeography, 38(7), 1356-1367.
Bobo, K.S., Ntumwel, C.B. (2010). Mammals and birds for cultural purposes and related conservation practices in the Korup area, Cameroon. Life Sci Leaflets, 9:226-233

Bobo, K.S., Weladji, R.B. (2011). Wildlife and land use conflicts in the Mbam and Djerem conservation region, Cameroon: status and mitigation measures. Hum Dimen Wild, 16(6):445- 457.

D urant, S., Mitchell, N., Ipavec, A. \& Groom, R. 2015. A cinonyx jubatus. The IUCN Red List of Threatened Species 2015: e.T219A50649567.

https:/ / dx.doi.org/ 10.2305/ IUCN.UK.20154.RLTS.T219A50649567.en. Downloaded on 30 July 2020.

Fomin, E. S. D. (2008). Royal Residences and Sacred Forests in Western Cameroon: The Intersection of Secular and Spiritual Authority. Journal for the Study of Religion, Nature \& Culture, 2(3).

Fubah, M. A. (2013). D o We Need Museums in the Western Grassfields? 1. African Research \& D ocumentation, (121), 35.

Fubah, M. A. (2014). The Changing 'Life' of the Buffalo/ Cow Horns and New Methods of Adaptation by Carvers/ Patrons in the Grassfields, Cameroon. African Studies, 73(1), 41- 57.

Fubah, M. A. (2016a). Modern museums in the palaces of the western $G$ rassfields, Cameroon. Afiika Foas 29(2).

Fubah, M. A. (2016b). Views about modern museums in the palaces of the Western Grassfields, Cameroon. International Journal of African Renaissance Studies-Multi-, Inter-and Transdisciplinarity, 11(1), 84-102.

Geary, C. M. (1988). Art and political process in the kingdoms of Bali-Nyonga and Bamum (Cameroon grassfields). Canadian Journal of 
African Studies/ La Revue canadienne des études africaines, 22(1), 11-41.

G homsi, E. (1985). O rganisation et fonctions des résidences royales dans les Grassfields du Cameroun: l'exemple de la chefferie Bamiléké de Bandjoun. Paideuma, 49-63.

Grace, J. (2015). Chieftaincy Reimagined: Modernity and Tradition in the Cheftaincy of Batoufam, Cameroon. Duke University, D urham.

Henschel, P., Coad, L., Burton, C., Chataigner, B., D unn, A., MacD onald, D. \& Hunter, L. T. (2014). The lion in West Africa is critically endangered. PLoS O ne, 9(1), e83500.

Humle, T., Maisels, F., O ates, J.F., Plumptre, A. \& Williamson, E.A. 2016. Pan trogodtes (errata version published in 2018). The IUCN Red List of Threatened Species 2016: e.T 15933A 129038584.https:/ / dx.doi.org/ $10.2305 / \mathrm{I}$ U C N.U K.20162.RLTS.T15933A17964454.en. Downloaded on 30 July 2020.

Ingram, V., \& Nsom, J. A. (2007). Plant and animal guide for the Western Cameroon Highlands. Nature \& Fauna, 22, 29-36.

IUCN SSC Antelope Specialist Group. 2019. Symeruscaffer. The IUCN Red List of Threatened Species 2019: e.T 21251A50195031. https:// dx.doi.org/ 10.2305/IUCN.UK.20191.RLTS.T21251A50195031.en. Downloaded on 30 July 2020.

Lamarque, F., Stark, M. A., Fay, J. M., \& Alers, M. P. T. (1990). Cameroon. Antelopes: Global Survey \& Regional Action Plans, part, 3, 90-99. Leonard, J. A . (2008). Ancient D NA applications for wildlife conservation. Molecular Ecology, 17(19), 4186-4196.

Lewison, R. \& Pluháèek, J. 2017. Hippopdamus amphibius The IUCN Red List of Threatened Species 2017: e.T10103A 18567364. https:// dx.doi.org/ 10.2305/IUCN.UK.2017-
2.RLTS.T10103A 18567364.en. Downloaded on 30 July 2020.

Maisels, F., Keming, E., Kemei, M., \& Toh, C. (2001). The extirpation of large mammals and implications for montane forest conservation: the case of the Kilum-Ijim Forest, North- $\mathrm{w}$ e s t Province, Cameroon. O ryx, 35(4), 322-331.

Marchal, H. et Perrois, L (1993). Les rois sculpteurs : art et pouvoir dans le grassland camerounais : legs Pierre Harter. Musée national des arts africains et océaniens, Réunion des musées nationaux.

Pemunta, N. V., \& Anye, N. D. (2019). Modern State Law: Regulating Tradition or Protecting the Environment in the Mankon Kingdom of Northwest Cameroon. In Endemic Spedes. IntechO pen, Rijeka.

Rowlands, M. (1985). Notes on the material symbolism of Grassfields palaces. Paideuma, 203213.

Rowlands, M. (2011). Of substances, palaces, and museums: the visible and the invisible in the constitution of Cameroon. Journal of the Royal Anthropological Institute, 17, S23-S38.

Rutte, C. (2011). The sacred commons: conflicts and solutions of resource management in sacred natural sites. Biological Conservation, 144(10), 2387-2394.

Talla R.T (2003). Ethnoarchaeology and Historical Archaeology of Mbajeng in Wimbum Land of Donga Mantung Division, Northwest Province of Cameroon. Unpublished.

Ph.D.Thesis, D epartment of Archaeology and Anthropology, University of Ibadan, $\mathrm{N}$ ige ria WWF (2020). The Cameroon Highlands ecoregion. https:// www.worldwildlife.org/ ecoregions/ at0103. 